\title{
Development of the communicative process in teaching and learning geometry through interactive mathematics software
}

\section{Carlos Rene Bautista Niño}

Instituto Técnico Agrícola Rafael Ortíz González, La Chacara Subsidiary, Colombia renebautistainfor40@gmail.com

\begin{abstract}
This qualitative approach research project, aims to strengthen the communication process in teaching and learning of mathematics, through resolution of geometric problems in an interactive mathematics software environment in 4th and 5th grade students of the escuela rural La Chacara, in the municipality of Santa Bárbara (Santander). Who excels at communicating, can also interpret and express situations in regard of mathematical contexts in a determined and specific language. These communicative abilities in the solution of a mathematical problem are cognitively related actions that imply verbal activity such as listening and speaking, summarizing, justifying, explaining, arguing, defining, dialoguing, commenting and discussing .This research intends to propose a didactic unit that promotes the development of the skills of the mathematical communication process: to justify, to argue, to identify and to interpret through the software of dynamic geometry. Also, to design a methodological strategy that allows to analyze the results of the incidence of software of dynamic geometry in the strengthening of the process of mathematical communication. As an intervention strategy, a didactic unit was designed and implemented in three sequences related to the study of three geometric figures: the square, the rectangle and the rhombus. The activities of the sequences were organized taking into account the learning phases of the Van Hiele model investigating in each one the skills of the communication process mentioned above. Pedagogical mediation through the use of digital technology, such as GeoGebra software, favored the teaching of geometry and improved the classroom environment and the learning environment. Finally, the students took a final test in order to verify the development of representation skills and, according to their results, a notable process in such skills and in the acquisition and interpretation of the main concepts regarding quadrilaterals properties became evident.
\end{abstract}

Keywords: Space Thought. Communicative Process. Communicative Skills. Dynamic Geometry Software. Didactic Sequence.

\section{Desenvolvimento do processo de comunicação no ensino e aprendizagem da geometria com a mediação do software matemático interativo}

\begin{abstract}
Resumo
Esse projeto de pesquisa-ação de foco qualitativo, tem como objeto fortalecer o processo de comunicação no ensino e aprendizado das matemáticas, através da resolução de problemas geométricos num contexto de software de matemática interativa nos alunos do 4 e 5 ciclo da escola rural a Chácara do município de Santa Barbara (Santander); Quem tem habilidades para comunicar, pode interpretar e expressar situações próprias dos contextos matemáticos numa linguagem determinada e específica. Essas habilidades comunicativas na solução de um problema matemático, são ações relacionadas de maneira cognoscitiva que leva implícita a
\end{abstract}

Revista de investigação e divulgação em Educação Matemática, Juiz de Fora, v. 3, n. 1, p. 72-94, jan./jun. 2019. 
própria atividade verbal, tal como: audição e expressão oral, resumir, justificar, explicar, argumentar, definir, dialogar, comentar, e discutir. Com essa pesquisa pretende-se propor uma unidade didática que promova o desenvolvimento das habilidades próprias do processo de comunicação matemática: justificar, argumentar, identificar e interpretar através do software de geometria dinâmica. Assim mesmo, desenhar uma estratégia metodológica que permita analisar os resultados da incidência do software de geometria dinâmica no fortalecimento do processo de comunicação matemática. Como estratégia de intervenção, desenhou-se e implementou-se uma unidade didática composta de três sequências que abordavam o estudo de três figuras geométricas: o quadrado, o retângulo, e o losango. As atividades das sequências se organizaram tendo em conta as fases da aprendizagem do modelo de Van Hiele indagando em cada uma as habilidades próprias do processo de comunicação já mencionadas. A mediação pedagógica através do uso da tecnologia digital como o software GeoGebra favoreceu a abordagem do ensinamento da geometria e permitiu o melhoramento do ambiente da aula assim como o entorno da aprendizagem. Por fim, aplicou-se aos alunos uma prova final para verificar o desenvolvimento das habilidades da representação e segundo os resultados obtidos, evidenciouse um avanço notável em ditas habilidades e a aquisição e interpretação dos conceitos das propriedades dos quadriláteros.

Palavras-chave: Pensamento espacial, processo de comunicação, habilidades comunicativas, software de geometria dinâmica, sequência didática.

\section{Introduction}

Whereas it is stablished that natural language is able to connect people socially, it is also true that mathematical language allows us to express ideas, understand expressions, comprehend in diverse ways of representation or notation and solve problems. This article is the result of self-reflection inside the teaching exercise and the development of a research work about the strengthening of the mathematic communicative process in a dynamic geometry environment.

This research was conducted with $4^{\text {th }}$ and $5^{\text {th }}$ grade students in a rural subsidiary school from a public institution in the municipality of Santa Bárbara. This project aims to strengthen the communication process through the resolution of geometrical problems, adopting the use of technological features, more specifically, the dynamic geometry software GeoGebra as the main pedagogical tool. Another goal is revising the methodological and pedagogical strategies the teacher uses, giving this task a new focus. The research project is based on the following considerations:

- Development of activities through processes, using specific activities in order to strengthen the mathematic communication process.

- Have students use their communicative skills to solve a geometrical problem.

- Stablish geometrical construction problems in such a way participants can produce valid arguments as they justify certain procedures. 
- Provide a space in which students can listen to strategies from their peers and express their own in mathematic language, in order to convince their peers or argue their ideas.

- Use of a dynamic geometry software, with proper activities regarding spatial thinking, taking into account the weaknesses in this topic, evidenced in the educational institution in which this research was conducted, (according to students' results in state tests), while orientation with numeric thinking continues to prevail in teachers' classes.

More precisely, the research problem comes from the necessity to overcome difficulties evidenced in pruebas saber (state tests) 2014 and 2015, in which the weaknesses in the communicative process and spatial thinking are clear.

In the pedagogical practice, that is to say in the classroom, communication is relegated to a second place since processes such as formulation and resolution of problems and the comparison and exercise of algorithmic procedures gain more attention from the teacher. Communication should gain the relevance it has for the understanding of mathematics, as it stimulates the ability to verbalize the language of the subject, helps understand the meaning of the symbols and serves as a support to use this language to represent, reflex and solve everyday problematic situations. It is a notorious fact that many of the students are restricted because they do not have adequate slang in mathematics, which limits and hinders the process of teaching and learning the subject. When one is not communicatively skilled in the use of the mathematical language (symbols, diagrams, algorithms, notations, amongst others.), the difficulty to have a good performance in the matter is almost assured. For the understanding and reach of mathematical competence, it is necessary to strengthen communication process skills such as arguing, interpreting, explaining and justifying, through solving problems in an interactive math software environment, because it is believed that this process is key to overcome difficulties in geometry learning.

Another aspect to take into account in the approach of the research problem, is to overcome the limitations of the teaching staff due to focusing their teaching of the subject in content and not in processes. In this way, a specific content must be conceptualized from the point of view of communication, practice, problem solving, reasoning and modeling. If a topic is approached from a single perspective, it will cause understanding problems, and as it advances, the obstacle of a misunderstood or 
incomplete concept will be dragged. Making it in the future be marked as an error or ignorance on the part of the student and not as a bias produced by the mono directional approach given by the teacher to the topic.

When a teacher is aware and questions the fact that his or her students do not understand mathematics, other questions, which aim to clarification of this fact, arise: Do I make myself understood in class? Do I apply innovative strategies in my pedagogical practice? Does my class become a simple workshop on algorithm solving practice? This reflexive space leads to find problems which affect directly the difficulty for learning mathematics ranging from lack of motivation to social and/or family problems. In the end, when the teacher - student relationship in the classroom is addressed, there is only one problem to analyze; communication.

While addressing the teacher-student relationship as a communicative act, under self-evaluation of the teaching process, it is possible to unveil situations that respond to students' learning difficulties such as:

$\checkmark$ In the communicative act, the teacher's intervention prevails.

$\checkmark$ Different languages are spoken in the teacher-student relationship.

$\checkmark$ Mathematics appeal to students as a mere symbolic representation lacking value or meaning.

It is important to state that mathematics, despite not being a language, have constituted one per se in which it is possible to communicate, express, represent, read and write. Acquisition and mastery of languages, proper to mathematics, needs to be a diligent and thorough task for whom wants to be competent in it, as being able to handle this may result in frequent discussion about representation and symbolism and, in this way urge collective work.

Whom is skilled at communicated, is also able to interpret and express situations regarding mathematical contexts in a determined and specific language. This communicative skills, in a mathematical process, are cognitively related actions which implicitly carry communicative activity such as: listening and spoken expression, summarizing, arguing, defining, dialoguing, commenting and discussing ${ }^{1}$.

\footnotetext{
${ }^{1}$ FAUSTINO, Arnaldo; DEL POZO, Emilia; ARROCHA, Olaysi. Fundamentos epistemológicos que intervienen en el desarrollo de la comunicación matemática. Editado para la Fundación Universitaria Andaluza Inca Garcilaso para Eumed.net. Disponible en: <http://www.eumed.Net/librosgratis/2013/1279/Index.htm>. 2013.
} 
Arguing skills are essential for both, either strengthening mathematical thinking and organizing and establishing sequences, stating conjectures and corroborating them and in the same way, establishing concepts, judgements and reasoning which can provide coherent and logic support to the mathematical process ${ }^{2}$.

The strengthening of the ability to argue, brings with it the development of communicative competence, because when a student argues, he handles mathematical language adequately ${ }^{3}$. When it comes to the role of the teacher to develop the ability to argue, the teacher must have enough tools to learn to ask questions that require argumentations or other written or oral activities (dialogues) that strengthen the communication process through mathematical expression.

Regarding the ability of interpretation, it important to highlight that involves certain thought processes, and for the development of this skill it is required that when the student faces a mathematical problem he or she would need to:

- Determine the problem's nature by performing a general scan of it.

- Identify and define the variables present in the situation.

- Take advantage of representation systems in order to obtain a solution way.

- Discriminate the informative text from the imperative text. The structure of a problematic situation is formed by these two kinds of test. The informative text is the one, which contains the problematic situation itself, and the imperative text is the one, which points out what needs to be found.

- Identify the relationships between variables involved in the problematic situation.

- Making a scheme or translate the previous steps to a representation system ${ }^{4}$.

Interpretation follows veracity criteria, which not only imply the comprehension of contexts but also must lead to a concrete situation and reflect about its impact and the

\footnotetext{
2 FAUSTINO, Arnaldo; DEL POZO, Emilia; ARROCHA, Olaysi. Fundamentos epistemológicos que intervienen en el desarrollo de la comunicación matemática. Editado por la Fundación Universitaria Andaluza Inca Garcilaso para eumed.net, Disponible en: <http://www.eumed.net/librosgratis/2013/1279/index.htm>. 2013.

${ }^{3}$ Zabaleta, portillo. 2013

${ }^{4}$ Herrera, 2012.
} 
thinking processes involved with memories, comprehension, analysis, measuring, amongst others ${ }^{5}$.

The word justify is a term that represents an idiomatic repetitive use, applied to diverse situations. It refers to the process of demonstrating and supporting a statement with proofs and explaining a procedure or behavior based on certain motives.

Justification happens when a mathematical process is supported with arguments in order to achieve adhesion ${ }^{6}$.

Justification in mathematics refers to the activities and processes through which a statement is supported, its reason is presented, a conclusion is admitted or refused through relevant arguments like the development of a procedure, the statement of a determined strategy or the presentation of an example in order to achieve adhesion to a thesis.

When referring to the explanation skill it is taken into account that explaining implies clarifying a determined phenomenon or situation. Mathematically, explanation is considered as a primary idea from which the proof and the demonstration branch ${ }^{7}$.

Explanation is also a means to link ideas together, providing one or more reasons for data comprehension of data, a phenomenon or a result ${ }^{8}$.

For the national council of mathematics teachers, NCTM the ability to explain is considered as clarifying the answers in a determined procedure, implementing an increasingly strict language as the students' educational level advances.

During the development of this research, the proposed activities to evidence their explanation ability procured that students were able to express in written and oral ways, (using mathematical language) the strategies, predictions, conjectures and results while facing the resolution of a mathematical problem.

The research focused on strengthening the skills of interpreting, arguing, justifying and explaining. These mathematical skills are recognized as those capacities that are constituted during the realization of actions and operations that have a

\footnotetext{
${ }^{5}$ Niño, Rojas. 2005

${ }^{6}$ ICFES. 2012

${ }^{7}$ Pluvinaje, 2011

${ }^{8}$ Balacheff, 1982

${ }^{9}$ Duval, 1999
} 
fundamentally mathematical character. It was intended to be strengthen with the development of these skills: The ability of the student (when approaching a mathematical activity) to investigate or use concepts, properties, relationships, mathematical procedures, make different types of representation, employ work strategies, establish conjectures, make reasoning, make judgments and solve mathematical problems. Strengthened math skills demonstrate the level of conceptual mastery of a student, the ability to find alternative solutions to a mathematical problem in any context, showing the ability to communicate mathematically.

In correspondence to the procedural didactic focus, authorities in the matter state that "Communication is an essential component for mathematics learning because, through communication, students reflect, clarify and widen their ideas and the comprehension of mathematical relationships and reasoning". (Ministry of Education Ontario, 2005)

Mathematical communication is not an isolated process; it is linked to others like establishing and solving problems, in which there are necessary debates for the improving process based in arguments and sequential activities, are structured based on questions, answers and reasons; formalizing mathematic representations through reflection, as a tool for solving them.

\section{Findings}

\section{Result Analysis}

The didactic sequences planned for students to recognize the general features and properties of quadrilaterals, through resolution of a geometrical situation, aiming to strengthen their explanation, justification, argumentation and interpretation skills.

- There are evident weaknesses in the natural language used by students (elision of phonemes, lack of coherence and cohesion in their expressions, amongst others) which deprive them from communicating their ideas appropriately.

- Whether it is accepted that students use mathematical language in their arguments to refer to elements forming a quadrilateral (vertex, line segments, closed figure, amongst others), these concepts are not clearly handled, given that 
- They mention that these figures are formed by straight lines, collinear segments and one of them states that quadrilaterals' sides are all of the same length; considerations that show confusion and lack of knowledge about the essential properties of this figure.

- All students agree in pointing out that the sum of all interior angles in quadrilateral results in $360^{\circ}$. However, the ability to explain requires that students present the methodology they have implemented to solve the problem, or present their answers in front of the class and explain why they obtained those results. It is evident that in this case, students di not provide any explanation, but instead, they limited themselves just to express the sum's result. Despite not being a complex situation, the explanation ability requires of mathematic strictness, which students are lacking of in this context.

- The students were right when considering the quadrilateral they built as a polygon. However, when examining their justifying skill, their weaknesses became evident, as they presented their reasons for agreeing or refusing the given thesis, it was not possible for them to link them together using mathematical arguments. Students do not establish linking relationships between their arguments and the geometrical figures they refer to.

- None of the students explicitly state the conclusion to which they arrive after measuring the internal angles in the presented polygons. When analyzing their justification skill, it was possible to find that there exist weaknesses regarding this field in all of the students, as the validity and strength of their arguments is insufficient. Their natural language is not clear and their arguments are easily controvertible. They do not establish linking relationships between arguments and, when put under questioning it is possible to evidence that their reasons do not withstand replies. Thus, it is also evident that none of the students presented amongst their arguments, the methods they employed to solve the problem.

- Regarding justification skills, weaknesses are evident as students express their reasons and arguments for accepting or rejecting a presented thesis, they are not able to link them or to make them follow a mathematical leading path. Students do not establish linking relationships between elements in the geometrical figures they refer to. 
- The students experience more communicative difficulties while writing than while expressing their arguments orally.

- Arguments presented by students are merely notional. They support them with corporal representations in order to state a reason.

Taking into account that the results obtained from the sequence show the same tendency, the didactic sequence used will be presented below in order to evidence the methodology for establishing it and the analysis conducted to each of its phases.

The rhombus and its properties. This didactic sequence is planned for students to recognize the general features and properties of a rhombus, through the resolution of

A geometric problem, aiming to strengthen mathematical communication process skills.

\section{Information phase:}

\section{Activity 1}

In this phase, the students makes contact with the object of studies. For this, they were previously told to use the geometry software to build a rhombus from a rectangle by following specific directions. After the student determines the conservation of the rectangle's properties, he or she proceeds with the construction of the rhombus through the use of the "middle point" tool for each one of the segments conforming the initial polygon. The aim of this activity is to identify the following prior knowledge:

- Middle point.

- Mediatrix of a segment.

- Bisector of an angle.

- Congruent sides.

The objectives of the suggested activity aimed to the student identifying, comparing, and analyzing general features of a rhombus, besides strengthening the vocabulary used to describe it, boosting in this way the students' interpretation, justification and argumentation skills while solving simple questions.

Later, students answered some questions with the objective of assessing their explanation skill. The questions were proposed in the following way: 
Table 1: In which can I build a rhombus from a rectangle?

\begin{tabular}{|l|l|l|l|}
\hline CATHEGORY & S & ANSWER & SUBCATHEGORY \\
\hline \multirow{2}{*}{$\begin{array}{l}\text { Expression } \\
\text { mathematical } \\
\text { and natural } \\
\text { language of the } \\
\text { problem's } \\
\text { comprehension. }\end{array}$} & SA & $\begin{array}{l}\text { "I make a segment, then I use a perpendicular, } \\
\text { then a parallel and a bisection"(Sic) }\end{array}$ & Wrong \\
\cline { 2 - 4 } & SB & $\begin{array}{l}\text { "with the help of the parallel the perpendicular } \\
\text { the segment the drag test" (Sic) }\end{array}$ & Wrong \\
\cline { 2 - 4 } & SD & $\begin{array}{l}\text { "the first thing I did was to build a rectangle I } \\
\text { measured its angles and I used a polygon and } \\
\text { "I used the middle point tool then I used the } \\
\text { segment tool to link the dots I had made then } \\
\text { after linking the points I made a rhombus and I } \\
\text { deleted the rectangle" (Sic) }\end{array}$ & Wrong \\
\cline { 2 - 5 } & SE & $\begin{array}{l}\text { "I used the straight line to make the rhombus } \\
\text { sides and then I used the polygon to fill in and I } \\
\text { made the drag test". (Sic) }\end{array}$ & Wrong \\
\hline
\end{tabular}

Source: Own production.

Table 2: What happens to the sides' length when you apply the drag test?

\begin{tabular}{|c|c|c|c|}
\hline CATHEGORY & $\mathbf{S}$ & ANSWER & SUBCATHEGORY \\
\hline \multirow{5}{*}{$\begin{array}{l}\text { Expression in } \\
\text { mathematical } \\
\text { and natural } \\
\text { language of the } \\
\text { problem's } \\
\text { comprehension. }\end{array}$} & SA & $\begin{array}{l}\text { "That when we apply the drag test it doesn't } \\
\text { change at all and it doesn't change it remains at } \\
\text { all"(Sic) }\end{array}$ & Wrong \\
\hline & SB & $\begin{array}{l}\text { "it happens that the rhombus stays the same } \\
\text { and doesn't different measure" (Sic) }\end{array}$ & Wrong \\
\hline & $\mathrm{SC}$ & $\begin{array}{l}\text { "they become bigger, they become thicker they } \\
\text { become thinner and they become smaller when } \\
\text { I apply the drag test for that. They change, they } \\
\text { stay according to the angles but when you } \\
\text { make the diagonals and they measure its angle } \\
\text { it they don't change the angle when you apply } \\
\text { the drag test" (Sic) }\end{array}$ & Incomplete \\
\hline & SD & $\begin{array}{l}\text { "The measures in the sides when applying the } \\
\text { drag test it keeps the measures the same" (Sic) }\end{array}$ & Correct \\
\hline & SE & $\begin{array}{l}\text { "the square maintains and it doesn't change } \\
\text { when I apply the drag test". (Sic) }\end{array}$ & Wrong \\
\hline
\end{tabular}

Source: Own production.

The explanations given by students led to the following conclusion:

Revista de investigação e divulgação em Educação Matemática, Juiz de Fora, v. 3, n. 1, p. 72-94, jan./jun. 2019. 
- The students show difficulty when expressing through natural language, affecting their ability to explain so their explanation is given through expressions with no descriptive character. Their discourse is not clear, nor is perceptible the process of mathematical knowledge building. The use of strict mathematical language is not required in this skill. However, we can evidence that in the one hand, the student uses geometrical terms to communicate his or her predictions (without being correctly employed or learned) and in the other hand, the evident language vices present in all of them, undoubtedly difficult the normal flow of their mathematical communication.

Directed leading phase. Students were presented a geometrical problem. The suggested problem was intended to lead directly towards the results and properties students would need to know about the rhombus. The suggested problem is the following:

"A man buried a treasure in a plain. The map he left only showed a cross and a palm tree. He also wrote that the cross (Point A) and the palm tree (Point B) are the ends of the longest diagonal in a rhombus.

He called these vertexes vertex 1 and vertex 2 respectively. Besides, it showed that vertex 3 was to the north, 4 meters away from the middle point in the longest diagonal as the figure shows. All we know about the fourth vertex is that the treasure is in it. Where would you dig to find the treasure?

Find the place taking into account that it is essential for you to clearly know the properties of a rhombus before facing this problem".

Image 1: Localization through lines of a rhombus and the provided figure.

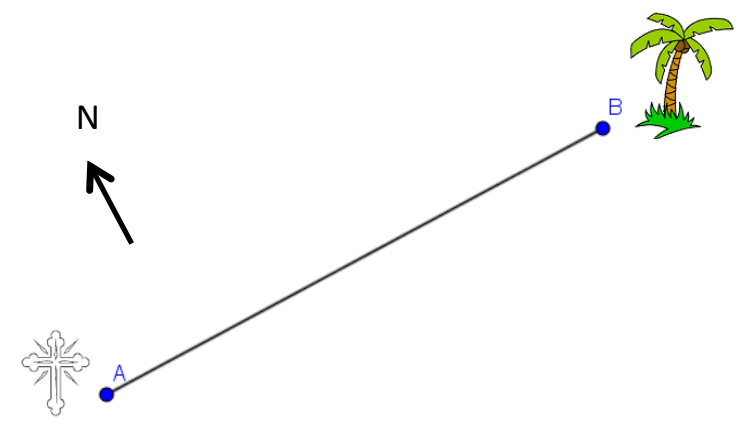

Revista de investigação e divulgação em Educação Matemática, Juiz de Fora, v. 3, n. 1, p. 72-94, jan./jun. 2019. 
In this case, the students observed a segment $\mathrm{AB}$ on the screen, which corresponded to the longest diagonal in a rhombus whose ends are vertexes.

Students were expected to use the compass to translate the $4 \mathrm{~m}$ long segment (in the treasure map) and find the location of the third vertex to then use any other tool in order to find the fourth vertex in the rhombus. Students must also prove that their construction withstands the drag test, verifying that the properties of a quadrilateral are present.

Image 2: Segment $\mathrm{AB}$ that corresponds to the longest diagonal in a rhombus and its ends.

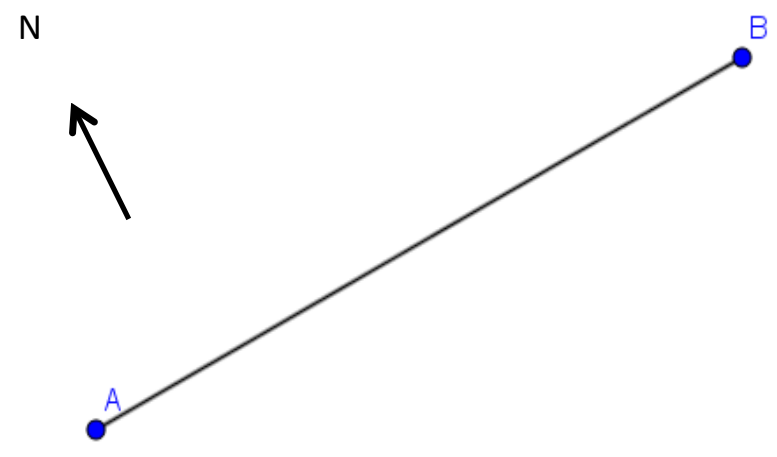

To start the development of the problem, students were asked to read it many times and take into account the location of the north. Then each student launched his or her strategy, without major guidance or work to be carried out by the teacher. The implementation of this activity is relevant as it has students initially produce conjectures through observation, and as the activity develops, they would have to focus on the rhombus' properties in order to build it and find the location of the treasure. The diagonal of a rhombus is the segment that was initially presented in an oblique position. The challenge for students consisted in finding the exact location of the treasure (fourth vertex), but they would only reach it if their construction complied with the properties of the rhombus. 
Image 3: Use of the "middle point" tool or "center" by students.

T: Teacher (D) SD: Students D (ED)

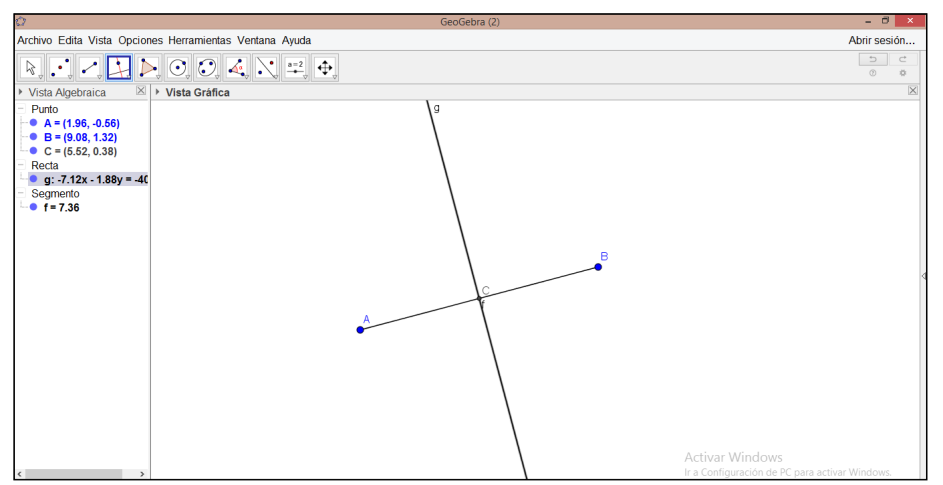

T: The third vertex is four meters to the north as shown by the arrow, how do you guarantee the accuracy of this measure?

SD: "So I place a point and then drag it until it shows four".

C: The student selected the point tool and placed one on the given perpendicular line. Then he used the "pick and move" tool, moving the point with the mouse along the perpendicular line. This situation was particularly awkward for the student as the round up was set to three decimal point. It was close to the measure but it was hard for him to place the point in the exact place to comply with the measure as shown in the graphic.

Image 4: Placing of the point at the required distance as shown in the graphic

$\mathrm{D}=(4.991,3.462)$
$\mathrm{E}=(4.764,4.285)$
Recta
$\mathrm{g}:-9.56 \mathrm{x}-2.64 \mathrm{y}=-56.854$
Segmento
$\mathrm{f}=9.918$
- Texto
TextoC $=$ "Cg=0"
TextoEC $=" \mathrm{EC}=3.968 "$

T: Now that you have achieved the third vertex, how do you finish the construction?

SD: "Now I link the points using segment". 
Image 5: Triangle drawing

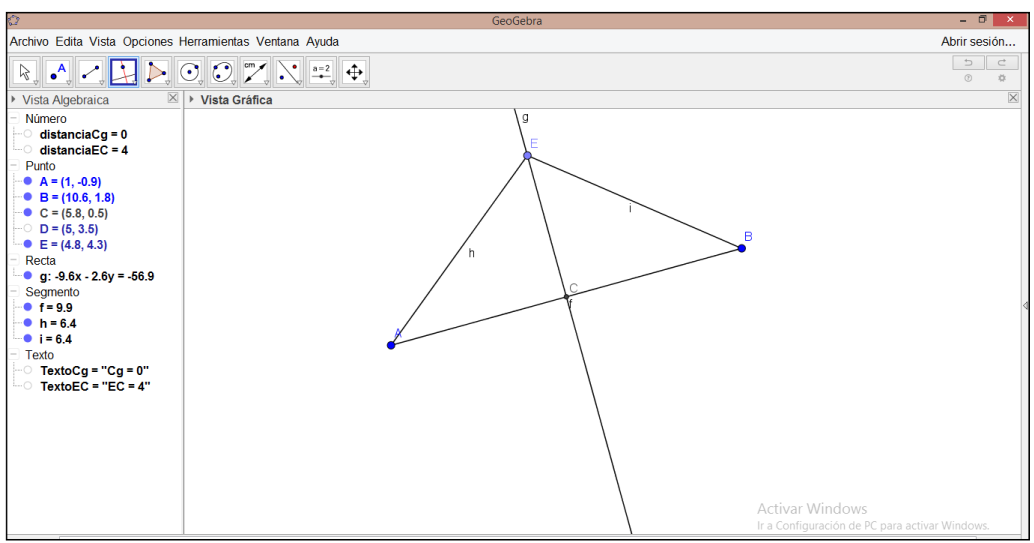

T: But what the screen shows is a triangle, how do you finish building the rhombus?

SD: "I draw a perpendicular to the diagonal and the missing point will appear"

Image 6: Drawing of a perpendicular to the diagonal and the missing points will appear.

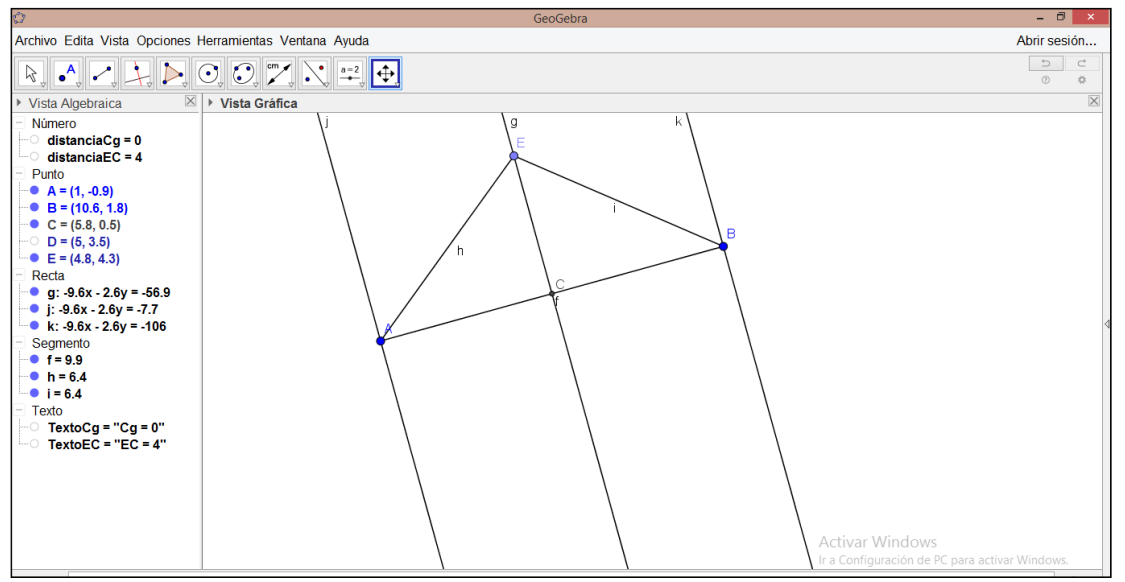

SD: "And then the parallel to the other line and there you have the polygon" 
Image 7: Parallel to the other line and there you have the polygon.

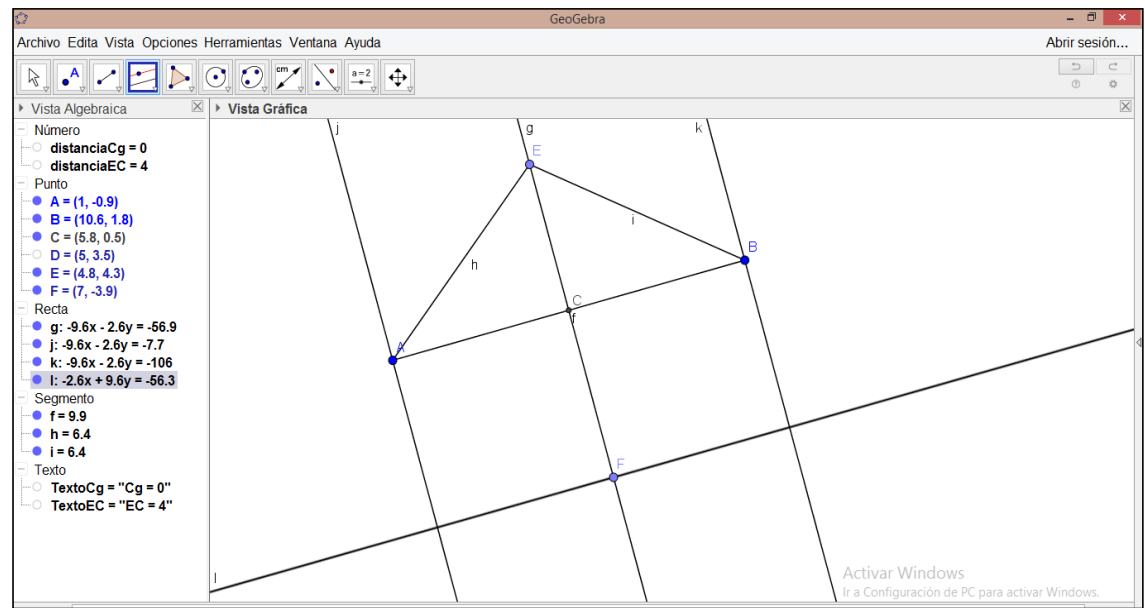

T: The student drew a parallel to the diagonal and placed a cutting point on the perpendicular line, touching the middle point in a random way. He did not realize that in this way, he will not only not guarantee the equidistance between the middle point, the diagonal and the third vertex, but also, the figure does not comply with the properties of a rhombus.

The student draws a parallel to the diagonal and places a perpendicular line touching the middle point in a random way.

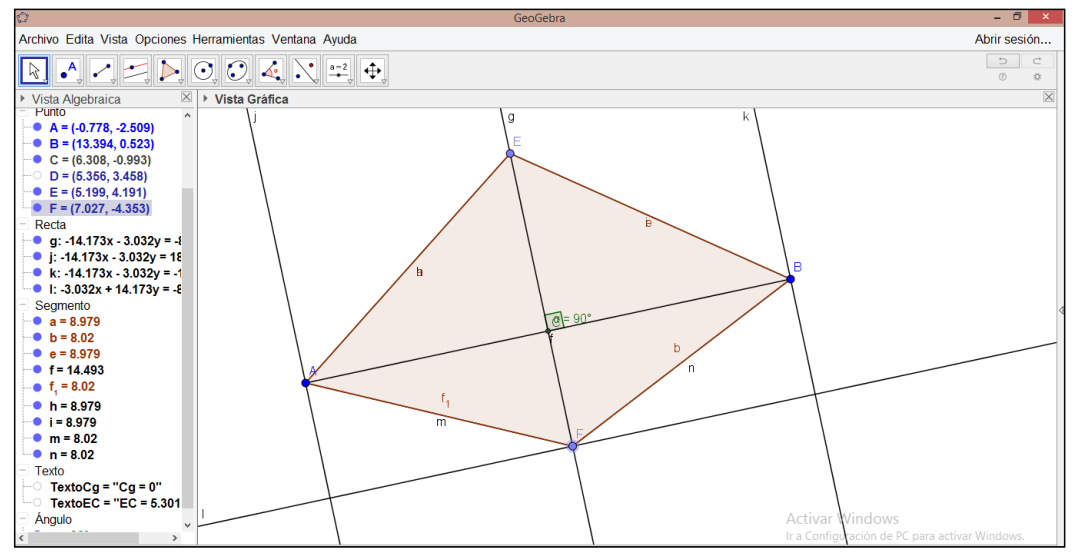

Table 3: In which way can you find the third vertex in the rhombus? Explain your answer.

\begin{tabular}{|l|l|l|l|}
\hline CATHEGORY & S & ANSWER & SUBCATHEGORY \\
\hline & SA & $\begin{array}{l}\text { "I drew a perpendicular and one that went } \\
\text { through the middle point and the I made a }\end{array}$ & Incomplete \\
\hline
\end{tabular}

Revista de investigação e divulgação em Educação Matemática, Juiz de Fora, v. 3,

n. 1, p. 72-94, jan./jun. 2019. 


\begin{tabular}{|c|c|c|c|}
\hline \multirow{5}{*}{$\begin{array}{l}\text { Expression in } \\
\text { mathematical } \\
\text { and natural } \\
\text { language of the } \\
\text { problem's } \\
\text { comprehension. }\end{array}$} & & $\begin{array}{l}\text { segment until it showed } 4 \text { and I dragged the } \\
\text { measure until I placed it with the compass" } \\
\text { (Sic) }\end{array}$ & \\
\hline & SB & $\begin{array}{l}\text { "I drew a perpendicular to the diagonal of the } \\
\text { middle point in the rhombus" (Sic) }\end{array}$ & Incomplete \\
\hline & $\mathrm{SC}$ & $\begin{array}{l}\text { "I used the compass and it said I had to } \\
\text { measure } 4 \mathrm{~cm} \text { upwards so I drew a } \\
\text { perpendicular to the diagonal that went through } \\
\text { the middle point and I made it pass through the } \\
\text { middle point" (Sic) }\end{array}$ & Wrong \\
\hline & SD & $\begin{array}{l}\text { "When I drew a perpendicular to the diagonal I } \\
\text { drew a point and moved it until it showed } 4 \text { and } \\
\text { I could find it" (Sic) }\end{array}$ & Incomplete \\
\hline & SE & $\begin{array}{l}\text { "Using the ruler I place it and I draw a } \\
\text { perpendicular until it shows } 4 \text { and passes } \\
\text { through the middle". (Sic) }\end{array}$ & Wrong \\
\hline
\end{tabular}

Source: Own production.

The explanations given by students for the construction of their rhombus and the processes presented by them, show that it was quite difficult and inconvenient for students to find the third vertex, not only because of its location, but also because of the distance between the middle point, the diagonal and the third vertex. The students' explanations do not reflect the descriptive character of the process, instead, they are the evidence of non-linked ideas and do not reflect communicatively how they reached the solution for the problem.

Table 4: Can diagonals in a rhombus be non-perpendicular? Why? Explain your arguments.

\begin{tabular}{|c|c|c|c|}
\hline CATHEGORY & $\mathbf{S}$ & ANSWER & SUBCATHEGORY \\
\hline \multirow{5}{*}{$\begin{array}{l}\text { Analyze the } \\
\text { criteria to give a } \\
\text { solution to a } \\
\text { problematic } \\
\text { situation parting } \\
\text { from facts. }\end{array}$} & SA & $\begin{array}{l}\text { "They cannot be perpendicular because if they } \\
\text { were unequal they would not be perpendicular } \\
\text { "(Sic) }\end{array}$ & Wrong \\
\hline & SB & $\begin{array}{l}\text { "no, because sides are equal and can't be } \\
\text { different to thos of the rhombus" (Sic) }\end{array}$ & Wrong \\
\hline & $\mathrm{SC}$ & $\begin{array}{l}\text { "no, because the sides in the rhombus are } \\
\text { equal. If the diagonals are not perpendicular the } \\
\text { shape is not a rhombus" (Sic) }\end{array}$ & Correct \\
\hline & SD & $\begin{array}{l}\text { "No, because if the diagonals' length was not } \\
\text { equal the polygon would not be a rhombus" }\end{array}$ & Wrong \\
\hline & SE & $\begin{array}{l}\text { "The diagonals must be perpendicular because } \\
\text { those are the rhombus' diagonals". (Sic) }\end{array}$ & Incomplete \\
\hline
\end{tabular}

Source: Own production.

Revista de investigação e divulgação em Educação Matemática, Juiz de Fora, v. 3, n. 1, p. 72-94, jan./jun. 2019. 
While analyzing the reasons presented by students, it is possible to conclude that there is evident weakness in arguing as:

- Their oral expression skill to agree or disagree a determined premise is limited, given that they do not employ models, counterexamples, valid reasoning or concrete proposals that persuade the listener about their statements.

- When putting their arguments under an acceptance test, it is possible to see that they are not pertinent to be accepted, due to the fact that they are easily arguable with a counterexample or the introduction of a consistent argument. For example, SB from whose idea is possible to infer that the length of either the diagonals or the sides of a rhombus are matching (like in a square). However, it is clear that in a rhombus, its sides are matching but not its diagonals, in which the dominant property is that they must remain perpendicular in a geometrical construction.

- The reasons presented by the students do not represent validity criteria, either because they are unlikely or because they are not convincing or just wrong, as in the case of student $\mathrm{A}$, who states that the diagonals in a rhombus "cannot be perpendicular". This false statement does not correspond to the basic properties in the studies of this kind of parallelograms.

Table 5: Later, students would complete the following information.

\begin{tabular}{|c|c|c|c|c|c|}
\hline \multicolumn{6}{|l|}{ RHOMBUS } \\
\hline CATHEGORY & STUDENT & $\begin{array}{l}\text { Do } \\
\text { diagonals } \\
\text { always cut } \\
\text { each other? }\end{array}$ & $\begin{array}{l}\text { Are diagonals } \\
\text { always } \\
\text { identical? }\end{array}$ & $\begin{array}{l}\text { Are diagonals } \\
\text { always } \\
\text { perpendicular? }\end{array}$ & $\begin{array}{l}\text { SUBCATHE } \\
\text { GORY }\end{array}$ \\
\hline \multirow{5}{*}{$\begin{array}{l}\text { Infiers } \\
\text { information } \\
\text { between } \\
\text { representation } \\
\text { systems. }\end{array}$} & SA & Yes & Not always & Yes & Correct \\
\hline & SB & Yes & No & Yes & Correct \\
\hline & SC & Yes & No & No & Incomplete \\
\hline & SD & Yes & No & Yes & Correct \\
\hline & SE & Yes & No & Yes & Correct \\
\hline
\end{tabular}

Revista de investigação e divulgação em Educação Matemática, Juiz de Fora, v. 3, n. 1, p. 72-94, jan./jun. 2019. 
Interpretation skills were assessed in students while extracting information from a graphic representation. Students were asked to answer about the cut, length and perpendicularity of the rhombus' diagonals. The results show that only one of the students (SC) made a mistake when recognizing the permanent perpendicularity of the figure's diagonals. The others, most likely supported by the visual aid presented on screen, were able to answer the questions correctly.

Explicitation phase: The students expressed orally the results obtained after solving the problem, they exchanged experiences and discussed about them with the teacher and their peers in order to become fully conscious about the features and relationships discovered and secure the technical language corresponding to the subject matter.

The students saw the need for using the right vocabulary (although with difficulty) to describe the construction on which they had been working. The kind of activity conducted in this phase is discussion and comments about the way in which the problem was solved. Elements, properties and relationships used or observed during the process.

It was evident that despite the experience of interacting with the software, and the need to urge students in using mathematic language to recognize certain properties of geometrical shapes they build, they persist in using endemic terms characterizing them as mathematical vocabulary:

Endemic terms used by students

\begin{tabular}{|l|l|}
\hline ENDEMIC TERMS AND EXPRESSIONS & ADEQUATE MATHEMATIC TERM \\
\hline Little ball & Circunference \\
\hline Little dot & Center of a circunference \\
\hline I took the measure & Translate a length \\
\hline The line they gave me & The given line segment \\
\hline I drew a line & I made a line segment \\
\hline
\end{tabular}

In this teaching and learning process about mathematics, it is very difficult to change oral and written language and the interpretation of representation systems a student use. It is clear that the student would use terms and expressions common to his or her social environment but, in order to participate in a mathematic communicative 
context it is necessary (or essential) to exercise in the use and interpretation of a new semiotic language which covers words and sounds linked to learning and writing new representation systems. Also with the proper interpretation of a system (graphic or algebraic) or with the fact of being able to clearly express their mathematical thinking. Communicative skills, as expressed by Duval (1999) "are essential either for designation of mathematical objects or communication and for work conducted with such objects". We can conclude that students continue to overlap natural language over mathematical language, characterizing words from their everyday life as mathematical vocabulary, as presented in the previous table.

\section{Free orientation phase:}

Look at the following figure

Activity suggested by the teacher

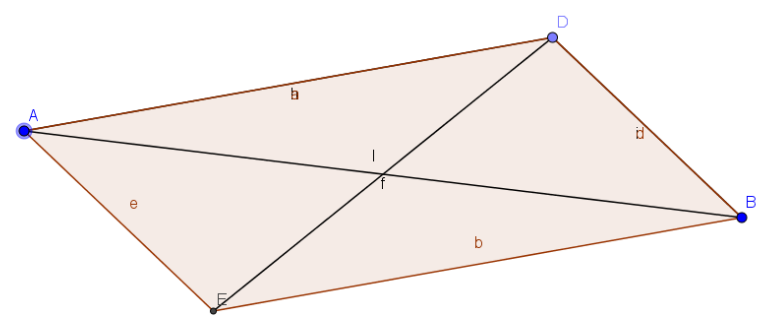

This activity consists in introducing a rhomboid so that students would determine whether it is a rhombus by checking its basic properties.

Table 6: Is the introduced figure a rhombus? Why?

\begin{tabular}{|c|c|c|c|}
\hline CATHEGORY & $\mathbf{S}$ & ANSWER & SUBCATHEGORY \\
\hline \multirow{4}{*}{$\begin{array}{l}\text { Infers } \\
\text { information } \\
\text { between } \\
\text { representation } \\
\text { systems. }\end{array}$} & SA & $\begin{array}{l}\text { "The figure is a rhombus because, after } \\
\text { applying the drag test to it it doesn't change its } \\
\text { shape" (Sic) }\end{array}$ & Wrong \\
\hline & SB & $\begin{array}{l}\text { "no, because if I apply the drag test it will } \\
\text { become a rectangle" (Sic) }\end{array}$ & Incomplete \\
\hline & $\mathrm{SC}$ & $\begin{array}{l}\text { "no, because the sides in a rhombus are equal } \\
\text { and in this figure they are not equal" }\end{array}$ & Incomplete \\
\hline & $\mathrm{SD}$ & "No, because diagonals do not measure $90^{\circ} "$ & Correct \\
\hline
\end{tabular}

Revista de investigação e divulgação em Educação Matemática, Juiz de Fora, v. 3, n. 1, p. 72-94, jan./jun. 2019. 


\begin{tabular}{|l|l|l|l|}
\hline & SE & $\begin{array}{l}\text { "It is a rhombus because it keeps its shape after } \\
\text { the drag test". (Sic) }\end{array}$ & Wrong \\
\hline
\end{tabular}

Source: Own production.

Arguments given by students reflect that they a considering the property of congruency in the rhombus' sides in order to produce them. It is evident that students in general are skilled in interpreting a graphic representation, inferring information from it.

The students were right when considering the quadrilateral they built as a polygon. However, while examining their argumentation skill, weaknesses became evident. While presenting their reasons and arguments for agreeing or disagreeing the given thesis, they are unable to link them together, and there is no mathematical path, which binds them. The students are unable to establish linking relationships between elements in the geometrical figures being referred to.

Integration phase. In this phase students establish a global perspective of what they have learned about the matter, integrating this new knowledge, methodology and reasoning guidelines to those they knew prior the activities. The suggested activity for this phase is to complete information and justify whether the statement they get is false or not.

Table 7: Integration phase
S: Student
T: True
F: False

\begin{tabular}{|c|c|c|c|c|c|c|}
\hline $\mathbf{S}$ & CATHEGORY & STATEMENT & $\mathbf{T}$ & $\mathbf{F}$ & JUSTIFICATION & $\begin{array}{l}\text { SUBCATHEGOR } \\
\text { Y }\end{array}$ \\
\hline SA & $\begin{array}{l}\text { Acceptance or } \\
\text { rejection of a } \\
\text { thesis through } \\
\text { relevant reasons. }\end{array}$ & $\begin{array}{l}\text { Diagonals in a } \\
\text { rhombus cut each } \\
\text { other in its } \\
\text { middle point. }\end{array}$ & X & & & Correct \\
\hline SB & & & $\mathrm{X}$ & & & Correct \\
\hline $\mathrm{SC}$ & & & X & & & Correct \\
\hline SD & & & $\mathrm{X}$ & & & Correct \\
\hline SE & & & $\mathrm{X}$ & & & Correct \\
\hline SA & & \multirow{4}{*}{$\begin{array}{l}\text { Diagonals in a } \\
\text { rhombus are } \\
\text { perpendicular } \\
\text { among }\end{array}$} & X & & & Correct \\
\hline SB & & & $\mathrm{X}$ & & & Correct \\
\hline \multirow[t]{2}{*}{$\mathrm{SC}$} & & & $\mathrm{X}$ & & & Correct \\
\hline & & & X & & & Correct \\
\hline
\end{tabular}

Revista de investigação e divulgação em Educação Matemática, Juiz de Fora, v. 3, n. 1, p. 72-94, jan./jun. 2019. 


\begin{tabular}{|c|c|c|c|c|c|}
\hline SD & themselves. & & & & \\
\hline SE & & X & & & Correct \\
\hline$\overline{\mathrm{SA}}$ & & & $\mathrm{X}$ & $\begin{array}{l}\text { "all sides must be } \\
\text { congruent } \\
\text { otherwise it is not a } \\
\text { rhombus" }\end{array}$ & Incomplete \\
\hline SB & $\begin{array}{l}\text { Opposite sides in } \\
\text { a rhombus are not } \\
\text { congruent }\end{array}$ & & $\mathrm{X}$ & $\begin{array}{l}\text { "the sides in a } \\
\text { rhombus are all } 4 \\
\text { of the same } \\
\text { measure" }\end{array}$ & Incomplete \\
\hline $\mathrm{SC}$ & & & $X$ & $\begin{array}{l}\text { "no, because all of } \\
\text { them measure the } \\
\text { same" }\end{array}$ & Incomplete \\
\hline$\overline{\mathrm{SD}}$ & & & $\mathrm{X}$ & $\begin{array}{l}\text { "they must be } \\
\text { congruent } \\
\text { otherwise it would } \\
\text { not be a rhombus" }\end{array}$ & Incomplete \\
\hline SE & & & $\mathrm{X}$ & $\begin{array}{l}\text { "if the shape } \\
\text { moves, the sides } \\
\text { must be of the same } \\
\text { measure" }\end{array}$ & Incomplete \\
\hline
\end{tabular}

Source: Own production

The students apprehended some of the properties of the rhombus as the perpendicularity of its diagonals and the congruence of the sides that make it up. However, when examining the ability to justify, weaknesses are evident, because when presenting their reasons or arguments to reject the thesis, they simply deny the proposed thesis, without supporting their disagreement with the thesis with other proposals, or counterexamples.

\section{Conclusions}

While it is true that natural language allows us to communicate socially, it is no less true that mathematical language allows us to express ideas, understand expressions, understand different forms of representation and solve problems.

One of the relevant conclusions of this research process is the fact of detecting that in the learning of mathematics, the semiotic vocabulary characteristic of the area is greatly influential. The way in which the student builds knowledge is also affected, 
because, it is not only a matter of incomprehensible concepts, but also the way in which they reach the student through the "language" used by the teacher.

Precisely, one of this research's expected results was that the teacher should assess his or her practice, and feel the need to become a communicator; a task which is not achieved short term but in the process of reinforcing the teacher's disciplinary knowledge and guiding his or her practice to the strengthening of his or her methodology. According to the obtained results, it is important to highlight that in the case of the researching teacher, it was possible to accomplish the goal of giving value to the importance of the use of an adequate mathematical jargon to teach such subject.

This is why the aim was to strengthen the communicative skill in students through the activities in this research. The design of each of the didactic sequences complied with the purpose of reinforcing the communicative process skills such as argumentation, explanation, justification and interpretation based on a problem solving focus.

Precisely, while observing the obtained results in each one of the sequences, it is evident that there are serious faults in the students' expression, including natural language such as the use barbarisms, elision of phonemes and dysgraphia that prevent them from expressing any idea fluently.

When referring to abilities proper of the communication process, it is important to state that there exist notable faults in most of the students. Amongst them, we find that arguments, reasons and explanations provided by students do not reflect consolidated mathematical knowledge besides not belonging to the deductive nature. It is evident that the arguments presented by them were not formed by clear words or examples in which the process of resolution of a problem is not perceptible.

After bringing arguments, reasons, justifications and explanations under the process of resolution of a mathematical problem, it is possible to find that these are not pertinent in terms of acceptance, because they are easily arguable by a counterexample or the presentation of a consistent reason.

It was possible to observe that students present difficulties when moving from natural language to mathematic language or from an oral representation to a graphic one.

Thanks to the recognized difficulties, it was possible to establish the importance of focusing the mathematical teaching process in the development of processes rather 
than contents. These, seen as knowledge that has to be learned and mastered, can be considered as a worthy reason for the development of skills.

To finish, it is important to highlight that the mediation of the dynamic geometry software, brought notable repercussions to the way of approaching the study of geometry. The interaction of students with their geometrical constructions favored the learning environment and improved the students' attitude towards the subject. The software allows us to clearly discriminate the features of a drawing from those of a geometrical construction, and permits to verify the properties of a shape through the drag test.

Finally, it is also important to bear in mind that in any field regarding mathematics teaching, it is essential to plan and execute activities which allow the strengthening of abilities proper to the communicative process. An in such way procure a gradual development, from the very first school grades, of the communicative abilities, stressing the use of mathematical language in order to form mathematically competent students.

\section{Reference}

BALACHEFF, Nicolás. Preuve et demonstration en mathematique au college. En Recherches en Didactique des mathematiques. v. 3, n.3, p. 261-304, 1982.

DUVAL, Raymond. Argumentar, demostrar, explicar ¿continuidad o ruptura cognitiva? Mexico: grupo editorial iberoamericana, 1999. p. 149-151.

FAUSTINO, Arnaldo. DEL POZO, Emilia. ARROCHA, Olaysi. Fundamentos epistemológicos que intervienen en el desarrollo de la comunicación matemática, Editado para la Fundación Universitaria Andaluza Inca Garcilaso para Eumed, net. Disponible en: <http://www.eumed.Net/libros-gratis/2013/1279/Index.htm>. 2013.

HERRERA, Diego. Evaluación de la competencia argumentativa en matemáticas. Universidad Nacional de Colombia. Medellín. 2012. p. 22-29.

ICFES. 2012

NIÑO, Víctor. Competencias en la comunicación. Hacia las prácticas del discurso. Bogotá. Colombia: Eco ediciones, 2005.

PLUVINAJE, Bertrand. Título del artículo. Revista Educación y Pedagogía. v. 23, n. 59, p. 85-102, ene./abr., 2011. 